\title{
HAM, AHMADIYAH DAN HETERODOKSI BERAGAMA
}

\author{
Bambang Saifull Ma'arif \\ Fak. Dakwah Unisba \\ Email: basmar_ali@yahoo.com
}

\section{Abstract}

This working paper elaborates guarantee of Universal Declaration of Human Rights (DUHAM) and the Basic Constitution (UUD) 1945 on freedom of religion and its implementation in Indonesia, as sell as bow the Abmadiyab, which is regarded as a religious beterodoxy, gets the freedom. Individual freedom to tive make them do accordance with their will is guaranteed by Universal Detlaration of Human Rigbts (DUHAM), including freedom of religion and belief. But in practice, especially in Indonesia, Ahmadiyah get many obstacles to practice their faith, particularly wben doctrine (understanding) believed by a person or group does not accord with the given or. old understanding. As a result, the freedom of religion is tied. In fact, buman freedom is guaranteed by Universal Declaration of Human Rights (DUHAM).

مبندم:

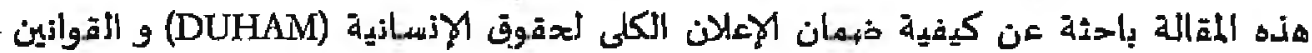

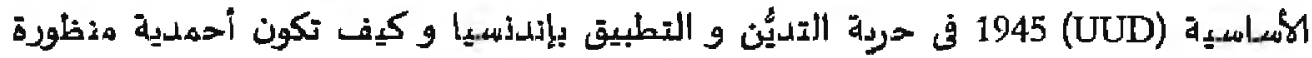

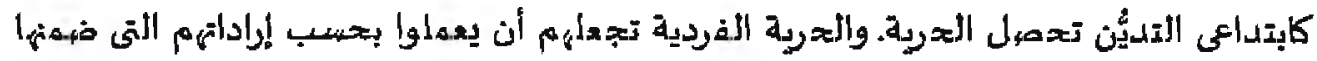
DUHAM خأصيا بإندنسيا. وهذه الحال أكثرإلحوادث إذا تكون المثاهم الثى اتيعها أحلد و قوم ليست فيها

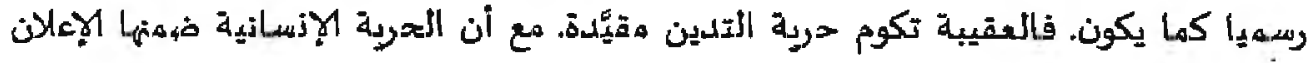
الكلى إلجةوق 1لإنهـانية.

Keywords. HAM, Heterodoksi, Ahmadiyah, Aliran Sempalan 


\section{A. Pendahuluan}

Individu dan masyarakat beraktivitas secara bebas karena dijamin hak asasinya. Kondisi ini terjadi karena Deklarasi Universal Hak-Hak Asasi Manusia (DUHAM), yang dimaklumatkan oleh PBB pada 10 Desember 1948. Implikasinya adalah bahwa manusia merupakan makhluk yang bebas dan merdeka secara moral, sehingga ia menjadi insan yang bertanggungjawab, baik secara sosial, moral dan hukum. Di samping hak, manusia juga punya kewajiban yang inheren. Antara keduanya ibarat dua sisi mata uang yang saling mendukung.

Manusia dijamin hak-hak keberagamaannya, tetapi dalam realitasnya kadang muncul problem yang menghambat di dalam menjalankan agama. Misalnya, dalam konteks kehidupan beragama di Indonesia, paham yang dipandang berbeda dengan pandangan mayoritas seringkali terkendala dalam menjalankan agamanya. Kebebasan kehidupan beragama adalah mutlak, karena ia merupakan kebebasan yang utama (the first freedom). Persoalan muncul ketika ada suatu paham keagamaan yang prinsip ajarannya sangat bertolak belakang dengan prinsip aqidah Islam. Misalnya, pada Ahmadiyah, yang mengakui adanya nabi lain setelah Nabi Muhammad Saw. Memunculkan sikap dan perilaku pro dan kontra.

Artikel ini membahas beberapa hal, yaitu: Jaminan DUHAM dan UUD 1945 akan kebebasan beragama; Ajaran Islam tentang HAM dan jaminan Islam akan kebebasan memeluk agama; Opsi yang ditawarkan kepada suatu aliran keagamaan ketika ia bertolak belakang dengan ajaran Islam, sebagaimana terjadi pada Ahmadiyah.

\section{B. Sejarah dan Konsepsi HAM}

Convenan HAM dicetuskan oleh Majelis Umum PBB pada tanggal 10 Desember 1948 melalui resolusi 217 A (III). Terdiri dari Mukadimah dan Isi, yang semuanya terdiri dari 30 Pasal. Hak-Hak asasi manusia selalu dipandang sebagai sesuatu yang mendasar, fundamental atau penting. Perspektif HAM PBB bersifat humanistik, dalam artian bahwa semua manusia dijamin hakhaknya sehingga dapat menjalankan semua tugas dan aktivitasnya dengan baik, 
tanpa ada gangguan dan rintangan. Manusia diciptakan oleh Tuhan sebagai makhluk yang mulia, maka dia harus dimuliakan dalam setiap fase perkembangannya.

DUHAM menjamin hak asasi manusia yang harus diimplementasikan oleh lembaga-lembaga pemerintah dan masyarakat: Penegasan itu dipastikan dengan adanya masalah kemerdekaan manusia untuk bertindak sesuai dengan pikiran dan keyakinannya. Deklarasi Hak Asasi Manusia (Bill of Rights) menandai suatu babakan baru bagi seluruh manusia yang terlahir memiliki kebebasan dan keadilannya. Sehingga penjajah dan perbudakan diakhiri oleh umat manusia, terutama oleh para raja dan kaum kapitalis.

Pengertian HAM menurut B. Mayo" adalah, "Suatu tuntutan, untuk seluruh manusia, untuk bersama-sama bertindak (atau barangkali, tidak bertindak) sebagian atas apa yang dikerjakan sebuah lembaga untuk memenuhi tuntutan." Pengertian tersebut lebih menekankan kepada persamaan. Sementara itu, M. Cranston mendefiniskan HAM sebagai, "Suatu hak moral yang universal, suatu yang harus dimiliki semua manusia, di manapun dan dalam waktu apapun, dan merupakan sesuatu di mana seseorang tak dapat dicabut baknya tanpa adanya penghinaan yang berarti terhadap keadilan, sesuatu yang harus diberikan kepada setiap manusia." Selanjutnya, S. Hook, mengartikannya sebagai, "Tuntutan yang secara moral bisa dibenarkan, agar seluruh mansia dapat menikmati dan melaksanakan kebebasan dasar mereka, harta benda, dan pelayanan-pelayanan mereka yang dipandang perlu untuk mencapai harkat kemanusiaan."

Berdasarkan pemikiran sebagaimana diuraikan di atas penulis mengemukakan beberapa poin penting, bahwa HAM meliputi beberapa aspek sebagai berikut: 1) dia merupakan suatu jaminan moral tentang kebebasan setiap orang dalam menjalankan aktivitas, tuagas dan kewajibannya, 2) menjadi sarana bagi diperolehnya suatu kebebasan seseorang datam menjalankan apa yang dikehendakinya, sepanjang tidak merugikan, merusak dan menyakiti pihak lain, dan 3) berimplikasi adanya tanggung jawab baik secara individual maupun

1 Harun Nasution dan B. Effendy (editor), Hak Asasi Manusia dalam Islam, Terj. Badri Yatim, dkk, (Jakarta: Yayasan Obor Indonesia, 1995), hal, 15-37. 
secara kolektif. Hak Asasi manusia merupakan bentuk perlindungan manusia agar setiap orang dapat melaksanakan tugas dan kewajibannya dengan baik.

Pembicaraan tentang HAM bisa dilakukan oleh 2 kelompok pemikiran, yaitu: Pemikiran yang berbasis agama, dan pemikiran yang tidak berbasis agama (sekular). DUHAM yang ada kini jelas tidak berlandaskan ajaran agama. Sehingga deklarasi tersebut lebih bersifat kemanusiaan (humanistik) belaka. Semangat universalitas ini menjadi landasan pengembangan kehidupan yang bermartabat. Meski DUHAM tidak bersumber dari agama tapi dia menjamin kebebasan memeluk agama. Dia berkomitmen terhadap agama tersebut. Orang Barat berpendapat secara yakin bahwa "agama Kristenlah yang mempengaruhi sikap bahwa pihak-pihak yang berperang harus menghormati beberapa peraturan hukum selama peperangan berlangsung."2

Di samping DUHAM, ada instrumen International on Civil and Political Rights (ICCPR), yang sifatnya lebih mengikat secara hukum dibandingkan DUHAM. Karena sifatnya yang mengikat secara hukum (legally binding), maka Indonesia sebagai negara yang sudah meratifikasinya mempunyai kewajiban untuk memasukkannya ke dalam perundang-undangan nasional dan berkewajiban untuk melaporkannya secara periodik kepada Dewan HAM PBB. Ratifikasi kovenan internasional ini sudah dilakukan melalui UU No. 12/2005.

Diperlukan pemahaman yang lebih mendalam bukan semata-mata kepada DUHAM, melainkan juga ICCPR pasal 18, khususnya ayat 3 yang menyatakan, "Kebebasan untuk mengejawantahkan agama atau kepercayaan seseorang hanya dapat dibatasi dengan ketentuan berdasarkan hukum, dan apabila diperlukan untuk melindungi keamanan, ketertiban, kesehatan dan moral masyarakat, atau hak-hak dan kebebasan mendasar orang lain." (Pranawati dan Irfan, 2011: 35). Ayat 3 ini secara tegas menunjukkan bahwa sebenarnya, bisa saja suatu ketika terjadi pembatasn dalam beragama bila paham agama yang ditkuti oleh suatu kelompok dipandang berpotensi menganggu ketertiban umum, kesehatan moral masyarakat. Pengalainan di lapangan menunjukkan bahwa bila suatu agama yang dipandang menyimpang dari ajaran pokok yang berbasis kitab suci

2 M.A Boisard, Humanisme dalam Islam, terj. HM. Rasjidi, (Jakarta: Bulan Bintang, 1980), hal. 17. 
dan/atau pemahaman ortodoks yang berlandaskan teks, sehingga akibatnya adalah hilangnya hak dan kebebasan mendasar orang atau pihak lain tersebut.

Implementasi HAM tidak bisa dipisahkan dengan sejarah pertumbuhan suatu bangsa, terutama bila dikaitkan dengan agama dan kebudayaan. Hampir semua bangsa di dunia lebih tua daripada usia DUHAM. Sehingga tidak mudah mengubah tradisi agama atau kebudayaan yang telah berurat-berakar pada sejarah suatu bangsa. Dalam perspektif Islam, misalnya Jaminan kébebasan beragama selalu dinyatakan secara deklaratif, tetapi untuk berpindah agama, terutama pada negara Islam, tidaklah mudah. Sehingga bila seseorang akan berganti agama maka dia harus pergi dulu untuk masuk ke suatu negara yang tidak memberlakukan hukum Islam. Sebab dalam perspektif Islam, yang diimplementasikan oleh suatu pemerintahan, perpindahan suatu agama dipandang murtad, yang akan mendapatkan sanksi negara baik moral, sosial atau pun hukum. Demikian pula menyebarluaskan suatu paham/aqidah yang nyatanyata keliru, dan bertolak belakang dengan paham mayoritas, dapat dipandang meresahkan dan mencemaskan warga masyarakat. Keonaran yang kecil namun prinsipal dapat menyebabkan kekacauan dalam kehidupan masyarakat. Alih-alih menimbulkan onar, pelaku onar harus dieliminir oleh peraturan yang ada. Meski suatu peraturan tidak boleh bertolak bélakang dengan undang-undang yang lebih tinggi, tetapi dalam praktiknya selalu terjadi anomali dalam masyarakat. Kondisi ini bisa terjadi katena praktik perundangan relatif dipengaruhi oleh politik.

Pada praktiknya kebebasan manusia dibatasi oleh kebebasan manusia yang lain. Setiap orang memiliki ruang gerak yang memungkinkannya dapat mengekspresikan berbagai pikiran, jatidiri, paham dan karyanya, sepanjang tidak mengganggu pihak-pihak lain. Bila hal itu terjadi maka harus dilakukari berbagai langkah preventif dan preemptifnya. Kondisi seperti itu dilakukan méngingat pentingnya kelancaran dan kedamaian dalam kehidupan di dunia ini. Karena kebebasan yang tidak dibatasi oleh suatu peraturan akan dapat mengganggu kebebasan orang lain. Karena itu dilarang untuk menyebarluaskan agenda paham-paham yang bertolak belakang dengan prinsip agama dan atas nama 
agama yang ada. HAM tidak bisa digunakan untuk hal-hal yang merusak serta menciptakan kerawanan.

\section{HAM dalam UUD 1945}

Secara tegas UUD 1945 Republik Indonesia menjamin Hak Asasi Manusia, sebagaimana tertuang”pada Bab XA, mulai dari pasal 28 A sampai pasal $28 \mathrm{~J}$ (semua berjumlah 10 pasal). Melihat banyaknya pasal yang menjamin HAM dalam UUD 1945 (amandemen ke empat, 2002), berarti besar pula jaminan kebebasan atas hak asasi manusia Indonesia. Implikasinya adalah hak-hak asasi manusia Indonesia dijamin secara konkrit oleh konstitusi.

Bangsa Indonesia membentuk konstitusi yang pada gilirannya membentuk peradaban. Konstitusi Indonesia menjamin manusia Indonesia yang berkarakter dan bermartabat, sebagai penanda dari Peradaban Indonesia. Selama warga negara bertindak sesuai dengan koridor konstitusi, dia dijamin hak-haknya. Dalam kaitannya dengan artikel ini kita perlu membahas tentang Bab XI tentang Agama yang hanya terdiri dari satu pasal, yaitu Pasal 29, yang terdiri dari 2 ayat. Pada Pasal ini dinyatakan bahwa, (1) Negara berdasar atas Ketuhanan Yang Maha Esa; (2) Negara menjamin kemerdekaan tiap-tiap penduduk untuk memeluk agamanya masing-masing dan untuk beribadat menurut agamanya dan kepercayaannya itu.

Di samping UUD 1945, Indonesia juga mengenal Undang-Undang No. 1/PNPS/1965, tentang Penodaan Agama. Mahkamah Konstitusi memandang UU tersebut masih dipandang absah, meski sudah ada pihak-pihak yang mengajukan judicial review. Implikasi logis dari yurisdiksi ini adalah bahwa, Kebebasan Beragama dijamin oleh konstitusi kita, sepanjang tidak menodai suatu agama. Tetapi bila kebebasan beragama itu dipergunakan untuk menodai suatu agama maka harus dicegah agar tidak meresahkan, yang akan dapat menimbulkan kemarahan dạn anarki sosial.

Untuk mengetahui dengan benar apakah suatu paham yang dianut oleh seseorang atau kelompok telah menodai atau tidak perlu ditanyakan kepada para penganut agama yang mengaku telah dinodai dicemarkan itu. Pandangan mereka itu perlu diklarifikasi dimana letak penodaan atau penyimpangan itu. 
Klarifikasi dilakukan terhadap berbagai berbagai komponen penganut agama, mulai dari tokoh organisasi sosial keagamaan, para pemimpin birokrat dan tokoh-tokoh agama (religious opinion leader). Praktik seperti ini telah berlangsung sejak lama. Sehingga praktik suatu hukum yang datang belakang meski harus dilaksanakan, tetapi tidak dengan mudah menjalankannya.

Bila semua elemen umat Islam sudah menyatakan telah terjadi heterodoksi beragama oleh suatu pihak maka diambil kesepakatan secara-mufakat. Kesepakatan akan terjadinya suatu tindakan penodaan berimplikâsi secara hukum bahwa suatu pihak telah melanggar hukum. Penodaan agama dapat memancing emosi pemeluk agama yang justru dilindungi oleh UUD 1945. Kondisi ini dalam jangka panjang akan membawa kerugian bukan semata kepada keimanan, tapi juga pada keamanan yang berdampak luas.

\section{HAM dalam Perspektif Islam}

Dalam pandangan Islam, konsep HAM bukanlah hasil evolusi dari pemikiran manusia, namun merupakan hasil dari wahyu Ilahy kepada para nabi dan rasul sejak permulaan eksistensi umat manusia di atas bumi. Kondisi ini kembali kepada dua hal penting dalam ajaran Islam, yaitu: eksistensi manusia dan tujuan diciptakannya (manusia). Eksistensi manusia menurut Islam adalah sebagai khalifatullah fi t-ardl (pemimpin di muka bümi), sedangkan tujuan diciptakannya manusia (dan juga jin) diciptakan adalah untuk beribadah. Pada peran khalifah itu juga manusia juga memiliki nilai ibadah. Sehingga semua peranannya akan mendapatkan balasan yang setimpal.

Dalam perspektif Islam konsep HAM lebih luas daripada HAM yang dicetuskan oleh PBB, karena HAM PBB yang diberlakukan secara universal ini Iebih bersifat humanistik dan duniawi. Sementara dalam Islam segala sesuatu dapat bernilai ibadah, baik dalam artian makhdlab atau pun ghairumimakbdlab. Pekerjaan manusia dapat memiliki niläi duniawi (imanensi) maupun yang bersifat metafisik (transendensi). Berdasarkan petunjuk Ilahy itu Islam membagi hak-hak manusia ke dalam 2 (dua) kategori, yaitu: buquq Ilab (hak-hak Allah) adalah kewajiban manusia terhadap Allah SWT., dan buquq al-ibad (hak-hak manusia) merupakan kewajiban-kewajiban manusia terhadap sesamanya dan 
terhadap makhluk Allah lainnya. Perintah ibadah merupakan suatu kewajiban yang sangat ditekankan oleh Islam, sehingga melalui ibadahnya manusia dapat mengendalikan perilaku kehidupannya secara baik.

Dalam Islam tanggung jawab apapun yang dipegang manusia tethadap sesamanya telah ditetapkan oleh Allah SWT sebagai hak. Konsep HAM dalam Islam ditegaskan pada QS. Al-Isra (17): 70,

"Dan sungguh telah Kami muliakan anak keturunan Adam dan Kami bawa mereka di darat dan di lautan, dan Kami beri rizki mereka dengan rizki baik. Kami muliakan mereka dari banyak makhluk yang lainnya."

Manusia lahir dalam kondisi merdeka. Kemerdekaan dan dignitas (kehormatan)nya, semua itu sebagai nilai-nilai, dalam rangka hubungan dengan Tuhan. Manusia adalah terhormat karena ia bertanggungjawab. Dan pertanggungjawaban ini didasarkan pada kemerdekaan untuk memilih (Boisard, 1980: 116). Hilangnya kebebasan menjadikan manusia tidak bertanggungjawab.

Setiap manusia memiliki anggota badan, dan setiap anggota badan memiliki hak, seperti: mata memiliki hak, otak memiliki hak, demikian pula telinga, mulut dan anggota badan lainnya, yaitu hak istirahat yang harus diberikan secara baik dan berkecukupan. Anggota badan manusia harus dipelihara dari rasa sakit atau siksaan, karena bila salah satu anggota badan sakit maka bagian badan yang. lainnya akan merasakan sakitnya.

Islam menjaga kemerdekaan umat manusia. Wasiat Nabi Saw, yang disampaikan pada peristiwa Haji Wada', di Makkah:

Dengarlah ucapanku wahai manusia, karena saya tidak tahu apakah saya akan melihat kamu di sini tahun depan. Semua kebiasaan menyembah berhala (jahiliyah) telah dilenyapkan di bawah kaki saya. Orang Arab tidak lebih tinggi dari bangsa non-Arab, dan kaum non-Arab tidak lebih tinggi dari bangsa Arab. Kamu semua adalah anak Adam, dan Adam diciptakan dati tanah. Sungguh, seluruh Muslim adalah bersaudara. Budak-budakmu, betilah mereka makan sebagaimana kamu makan, dan berilah pakaian sebagaimana kamu berpakaian. Permusuhan berdarah yang terjadi di jaman Jahiliyah telah dilarang. Ingatlah Allah ketika kamu menggauli wanita. Kamu mempunyai hak atas mereka dan mereka pun berhak atas kamu. Sesungguhnya, kamu harus mempertimbangkan darah kamu masingmasing, hak milik dan kehormatan yang tak dapat diganggu gugat hingga Hari Pengadilan. Dengan sesungguhnya, seorang manusia hanya bertanggung jawab atas tindakannya sendiri. 
Berkaitan dengan HAM yang berlaku universal kini, mayoritas umat Islam menerimanya, kecuali bila bertolak belakang dengan ajaran agamanya. Ada 2 (dua) keberatan dari kaum Muslimin di berbagai belahan dunia Islam, baik diajukan oleh negera Islam atau oleh para ulamanya. Saudi. Arabia telah mengajukan keberatan tentang dua butir dari DUI-IAM itu. Demikian pula dalam pandangan ulama Indonesia masa lampau, menurut Hamka ada 2 (dua) hal yang masih tetap menjadi perbincangan di kalangan kaum Muslimin di Éra Reformasi ini, yang menjadi keberatan mereka yaitu 2 pasal. Pertama, pada pasal 16, tentang pernikahan. Dalam hukum Islam seorang Muslim tidak bisa dengan leluasa untuk menikahi wanita musyrik, sementara wanita Muslim 'Tidak boleh wanita Muslim dinikahi oleh Ahli Kitab (Yahudi dan Nasrani) dan Musyrikin (paganisme).

Sementara itu pasal 18, berkaitan dengan kebebasan beragama dan kehidupan: Di antaranya adalah paham tentang kebebasan untuk berpindah agama, dan untuk menikah dengan siapapun yang dicintainya. Dalam pandangan Islam, seseorang yang telah menjadi Muslim tidak bisa dengan sukarela berpindah kepada agama lain.

Dunia Islam (meliputi negara-negara Islam atau negeri yang berpenduduk mayoritas Muslim) telah melaksanakan prinsip-prinsip DUHAM sejak deklarasinya oleh PBB 1948, yaitu dengan meratifikasikan, menyosialisasikan dan mengimplementasikannya. Ada yang bisa dilakukan dengan bails, namun ada pula catatan yang perlu disempurnakan. Meski dalam praktiknya tidak bisa seideal yang diharapkan namun sudah ada maksud baik untuk mengaplikasikannya.

Ketika seseorang bebas memilih agama maka kebebasannya itu menjadi sepenuhnya didalam tanggungjawabnya. Pada saat dia sudah menjadi Muslim dituntut ketaatannya kepada aqidah dan syariah Islam. Artinya dia dipagari oleh teologi (aqidah) dan hukum agama yang-dianutnya itu, sehingga tidak boleh sembarangan bertindak semaunya. Karena ketaannya dalam melaksanakan agama itu dia akan tercatat sebagai orang yang shalih. Persoalan ini seringkali disalahmengertikan oleh non-Muslim, sehingga mereka mengambil kesimpulan

${ }^{3}$ Hamka, Studi Islam, H. Rusdi (ed), (Jakarta: Pustaka Panjimas, 1982), hal. 227. 
yang keliru tentang Islam, bahwa Islam tidak membolehkan seseorang berpindah agama atau menikahi siapa pun yang dicintainya. Sedangkan HAM Islam merupakan jaminan khas yang berbasis keagamaan.

Akan tetapi dunia Islam masih banyak yang melakukan pelanggaran kepada HAM seperti masih terjadinya buman trafficking (perdagangan manusia). Kondisi ini sangat memprihatinkan warganegara. Cukup sulit untuk menghilangkan sistem perbudakan di seluruh dunia, khususnya di dunia Islam. Perjuangan masih terus berlangsung.

Pada artikel ini penulis lebih memfokuskan pada 2 pasal DUHAM, yaitı kebebasan untuk menikah dan memilih agama. Untuk keperluan itu penulis mengkhususkan kepada elite. Bila dicermati ada 2 hal yang secara langsung berkaitan dengan agama, yaitu pasal 16 dan pasal 18. Pada pasal 16 ayat (1),

"Laki-laki dan perempuan yang sudah dewasa, dengan tidak dibatasi kebangsaan, kewarganegaraan atau agama, berhak untuk menikah dan untuk membentuk keluarga. Mereka mempunyai hak yang sama dalam soal perkawinan, di dalam masa perkawinan dan di saat perceraian." Ayat (2), "Petkawinan hanya dapat dilaksanakan berdasarkan pilihan bebas dan persetujuan penuh oleh kedua mempelai." Sedangkan pada pasal 18, "Setiap otang berhak atas kebebasan pikiran, hati nutani dan agama; dalam hal ini termasuk kebebasan berganti agama atau kepercayaan, dengan kebebasan untuk menyatakan agama atau kepercayaan dengan cara mengajarkannya, melakukaannya, beribadat dan mentaatinya, baik sendiri maupun bersama-sama dengan orang lain, di muka umum maupun sendiri."

Berlandaskan spirit DUHAM semua manusia dijamin hak-hak beragamanya, Manusia oleh DUHAM boleh memeluk agama apa saja, berpindab agama yang disenanginya kapan dan dimana saja, dan meyakini kepercayaan meski sesat sekalipun. Namun dalam praktik kehidupan beragamanya tidak seperti itu. Terjadi paradoks antara konsepsi dan praktik, yang dapat ditelusuri dari pengalaman sejarahnya. Karena pengalaman suatu bangsa ditimba dari realitas sejarahnya.

Fakta menunjukkan bahwa Dunia Islam menyambut HAM dengan baik sejak dicetuskannya, selama 33 tahun, sampai akhirnya dunia Islam memberikan catatan terhadapnya. Dunia Islam telah menyatakan keberatannya hanya berkaiatan dengan 2 (dua) pasal, yaitu pasal 16 dan pasal 18. Jadi butir-butir 
DUHAM lebih banyak yang disetujui dibandingkan dengan yang ditolak. Sehingga Dunia Islam mengadakan dua kali Seminar Internasional. Pertama di London Inggris tahun 1981 yang dipimpin oleh Khursyid Ahmad, dan kedua di Kairo Mesir tahun 1990.

\section{E. Islam dan Kebebasan Beragama}

Islam menjamin hak untuk memeluk agama sesuai dengan yang dikehendaki oleh seseorang. Kebebasan dalam memilih agama itu menjadikan setiap individu dapat diminta pertanggungjawabannya di hadapan mahkamah Ilahy nanti. Setelah seseorang memilih suatu agama maka dia bebas untuk menjalankan atau tidak menjalankannya. Karena masing-masing manusia akan dihitung dari amal yang telah dilakukannya itu.

Secara deklaratif Al-Quran menggambarkan kebebasan seseorang dalam memeluk suatu agama. 'Tidak ada paksaan dalam beragama' (QS. 2: 256), dan "kebenaran itu datang dari Tubanmu, barangsiapa yang mau siapa yang akan beriman silabkan, dan berangsiapa yang man ingkar maka silabkan ingkar." (QS. 18: 29). Dan "Bagimu agamamu dan bagiku agamaku." (QS. 105: 5). Ayat-ayat tersebut merupakan suatu jaminan akan kebebasan beragama. Setiap diri bebas memilih agamanya, tetapi apabila dia sudah memilih suatu agama maka dia harus komitmen dan konsekuen terhadap agama yang diikutinya, itu. Pemaksaan menghancurkan konsep tanggungjawab.

Kebebasan beragama perlu dinyatakan sebagai hak-hak sipil seseorang yang dijamin secara mutlak. Kehilangan kebebasan menjadikan sंeseorang tidak diminta pertanggungjawabannya. Al-Quran menyatakan, orang yang melakukan suatu tindakan menyimpang dan atau dosa pada kondisi tekanan atau penyimpangan, menjadikannya bebas dari tanggung jawab (bari min al-dzimmab), sehingga ia terbebas dari dosa (QS. 16: 106). Sehingga perpindahan agama karena ancaman atau keterpaksaan menjadikan seseorang bebas dari ancaman, Kecuali apabila hatinya pro kepada apa yang ditekankannya itu. Islam tidak pernah memusuhi orang untuk beragama Kristen, Hindu, Budha, Yahudi, Hindu dan Konghuchu. 
Islam merupakan agama yang penuh dengan rahmat dan kasih sayang kepada semua manusia. Tetapi dalam praktiknya, kasih sayang itu seringkali terhambat karena beberapa faktor. Misalnya karena perbedaan iman. Kaum Muslimin seringkali memandang non-Muslim sebagai penghalang dari praktik menjalankan syariat Islam. Pada masyarakat Plural, seperti Indonesia, hak kebebasan beragama dijamin oleh konstitusi Pasal 29. Perbedaan agama di Indonesia disikapi secara dewasa, bahwa Tuhan membolehkan seseorang untuk memilih agama selain Islam. Meski secara substantif diakui bahwa agama lain yang diikuti itu tidak diridhai.

Secara teologis, Allah dapat saja menjadikan semua manusia memeluk Islam, tetapi Allah tidak menghendakinya. Semua kebenaran datang dari Tuhan, siapa yang mau mempercayainya silahkan, dan siapa yang ingkar terhadapnya juga bebas. Keingkaran tidak diridhai oleh-Nya. Adanya kekufuran juga merupakan konsekuensi logis dari adanya kebebasan. Kebebasan memilih agama berkonsekuensi bagi lahirnya balasan bagi manusia. Hak manusia untuk mengikuti agama tidak boleh ditindas atau diberangus. Manusia diciptakan dengan hak kebebasannya, karena dengan kebebasan itu dia dapat menjalankan kewajibannya.

Meski kekufuran ada, tapi kekufuran tidak boleh menginjak-injak kebenaran suatu agama baik dalam bentuk eksklusif maupun inklusif. Al-Quran juga melarang Múslim untuk mencela dan menodai keyakinan agama non-Islam, karena mereka dapat saja membalas untuk menodai agama Islam. Demikian pula, Islam pun melarang Muslim menodai agamanya sendiri. Kebenaran wahyu dijamin oleh Allah SWT (QS. 15: 9) hingga akhir jaman, dan umat Islam diseru untuk masuk kedalam Islam secara paripurna (kaffab).

DUHAM menyatakan bahwa seseorang bebas memeluk beragama, berpindah agama atau keyakinan, dan bahkan tidak beragama pun bebas. Tetapi konstitusi Indonesia menghargai manusia beragama. Pada sila pertama dari Pancasila, "Ketuhanan Yang Maha Esa." Berarti manusia Indonesia diarahkan kepada manusia yang beragama. Pelaksanaan ajaran agama yang secara tertib dilakukan oleh masyarakat Indonesia menunjukkan bahwa insan Indonesia memiliki semangat keagamaan secara konstruktif. Itulah sebabnya paham 
komunis tidak ditolerir oleh bangsa Indonesia. Pelaksanaan agama - apapun agamanya --, selama agama tersebut diakui oleh negara dilakukan oleh bangsa ini dengan menggunakan cara yang santun dan elok, sampai akhimya muncul Era Reformasi ini, di mana masyarakat dapat mengemukakan pandangannya secara bebas dan bertanggung-jawab.

Bagi seorang Muslim yang sudah menjalankan ajaran agamanya dengan baik tidak mudah untuk meninggalkan agamanya dengan berbagai dalih. Komunitas muslim di Indonesia cukup toleran terhadap kebedaan agama, namun tidak untuk penghujatan dan penistaan agama. Mereka berupaya untuk menjadi Muslim yang paripurna dengan menerapkan ajaran Islam secara tulus, tanpa banyak interpretasi. Kelompok ini mengamalkan ajaran Islam yang melarang Muslim membuat perpecahan, sebagaimana tertuang pada al-Quran Surah Al-Taubah (9): 12, tentang pencercaan agama, (QS. An-Nisa [4]: 46); QS. 3: 103, QS. 42: 13 dan QS. 6: 159, dan QS. 30: 32, tentang pemecahbelahan agama.

Muslim bertoleransi terhadap pemeluk Kristen, Yahudi, Budha dan Hindu sedari awal. Karena pemilihan agama dibebaskan oleh Islam. Sedanglan untuk berpindah agama juga diperbolehkan oleh hukum Islam, meski pada dunia Islam perpindahan agama ditutup- kernungkinannya karena dapat mempengaruhi pihak lain untuk menyebarluaskan agama baru itu yang dapat memicu konflik. Tetapi Islam membedakan perpindahan agama dari penodaan agama. Peamahaman seperti ini tampak dari Judicial Revieny UU No.1/PNPS/ 1965 tentang penodaan agama yang menolak peninjauan untuk mencabut UU tersebut pada Mahkamah Konstitusi (MK) ${ }^{4}$. Penolakan MK tersebut menunjukkan bahwa masalah penodaan agama masih diberlakukan secara khusus dalam sistem perundang-undangan Republik Indonesia.

Pada saat Nabi Muhammad Saw. masih hidup, di akhir hayatnya telah ada kelompok penentangnya. Majid Ali Khan menyatakan:

Surat Musailamah (pembohong) yang berani memaklumkan diri sebagai nabi, "bahwa setengah bumi ini adalah miliknya dan setengah yang.lain milik bangsa

${ }^{4}$ R. Pranawati dan Irfan Abubakar, Modal Keberagamaan dan Integrasi Sorial, Gakarta: CSRC UIN Syarif Hidayatullah, 2011), hal. vi. 
Quraisy." Dari Muhammad, Rasulullah, untuk Musailamah si pembohong: Bahwa bumi adalah milik Allah dan Dialah yang mewariskannya kepada orang yang diridhai di antara para Hamba-Nya yang bertakwa. ${ }^{5}$

Ada dua orang lain yang mengakt sebagai nabi, yakni Thulaiha Zaim bin As'ad dari Nejed, tetapi ia takut terhadap Rasulullah Saw. sehingga dia tidak segera memaklumkan diri melainkan menunggu Rasulullah Saw wafat. Kedua adalah Aswad 'Ausi dari Yaman, yang dengan kekuatan magisnya ia' dapat mengumpulkan banyak pengikut. Ia bunuh gubernur yang diangkat oleh Rasulullah di Yaman lalu mendekati Najran.

Kelompok ini dipandang telah kufur, sehingga Khalifah pertama, Abu Bakar al-Shiddiq, mengambil langkah tegas terhadap mereka dan pihak-pihak yang menolak membayar zakat, yaitu Musailamah bin Habib (dikenal dengan alkadqdqab), karena menglelaim dirinya membawa wahyu. Kelompok ini menjunjung tinggi 'sunnah' Abu Bakar al-Shiddiq yang menempuh jalan memerangi para pembelot dari ajaran Islam. Ini menjadi konvensi yang kemudian diterapkan oleh sebagian pemimpin di dunia Islam.

Itulah sebabnya mengapa warganegara dapat memeluk agamanya dengan bebas. Mau menjadi Muslim atau non-Muslim pada hekekatnya bebas, tetapi tidak untuk pihak-pihak yang menodai agama. Warganegara dapat memilih suatu agama yang meteka kehendaki. Mengikuti satu agama tertentu kemudian menohok dari belakang adalah suatu permainan yang licik. Tohokan seperti itulah yang kini dirasakan oleh Muslim.

\section{F. Heterodoksi Beragama}

Heterodoksi (beterodox) menurut Betty Kirkpatrick ${ }^{6}$ diartikan sebagai, "a contrary to received or establisbed doctrines, principles or standards; beretical; not ortodox." Sedangkan Muriir Ba'albaki mengartikannya sebagai, “ibtida', khuruj 'an alijma', keluar dari ijma”; disebut pula dengan "bid"ab." Sementara itu Seve M. Dagun mengartikannya sebagai, "penyimpangan terhadap kepercayaan atau doktrin yang diterima." Suatu ajaran yang bukan ortodoks'. Ortodoks merupakan

5 Majid Ali Khan, Muhammad Saw. Rasul Terakbir, terj: Fathul Umam, (Bandung: Pustaka Salman ITB, 1980), hal. 255.

${ }^{6}$ Betty Kirkpatrick, Cassel Concise English Dictionary, (London: Cassel, 1993), hal. 639. 
'Ajaran yang bersumber dari kepercayaan yang mapan.". Ortodoks merupakan suatu ajaran yang sangat menekankan pentingnya iman yang benar dan lurus serta dogma yang tak bisa diganggu-gugat. Sehingga suatu ortodoksi merupakan upaya berpegang teguh kepada kepercayaan adat-istiadat yang kuno.

Pemaknaan itu kemudian dipahami sebagai ajaran yang berdasarkan pada nilai-nilai tekstual disertai pemahaman yang etis-kritis. Pemahaman heterodoksi pada tulisan ini dipahami sebagai, ajaran dan kepercayaan yang tidak bersandar kepada teks yang baku dan pemahaman yang tidak etis. Suatu paham dipandang heterodoks apabila menggunakan interpretasi yang jauh dari spirit Islam, sebagaimana yang diteladankan oleh Nabi Muhammad Saw., baik melalui interpretasi yang jauh dari semangat teks, sehingga pemahaman menjadi menjauh dari orisinalitas ajaran Islam. Dengan demikian heterodoksi agama intinya adalah penyimpangan suatu paham dari ajaran agamanya yang baku dan orisinal menjadi menyimpang. Penyimpangan yang terakhir (evolusi) berujung pada kondisi murtad. Perkembangan teologia seperti ini dihadapi oleh Khalifah kedua, Abu Bakar, dengan tegas. Bagi mereka yang menolak Islam dengan mengklaim diri sebagai nabi, menolak membayar zakat dan menerima wahyu, Abu Bakar memerangi mereka ${ }^{7}$. Setelah Rasulullah Saw. wafat, Abu Bakar terlebih dahulu memberikan peringatan ke daerah-daerah yang memberontak dengan diberi maklumat baik yang bersifat umum maupun yang khusus ${ }^{8}$. Dalam maklumat itu, Abu Bakar menyarankan mereka agar kembali ke pangkuan Islam. Sebagian mereka mau masuk Islam tapi sebagian lainnya menolak. Abu Bakar memerangi mereka dengan menggunakan pasukan yang sudah dipersiapkan oleh Rasulullah Saw. di bawah kepemimpinan Usamah bin Zaid'.

Murtad dapat diklasifikasikan ke dalam beberapa kelompok, yaitu: 1) yang mengklaim kenabian, 2) beberapa kelompok lain meninggalkan Islam dan kembali kepada keyakinan mereka yang lama di jaman jahiliyah, dan 3) Tidak

${ }^{7}$ Ahmad bin Zainy Dahlan, Al-Fath al-Mubin fí Fadbâil al-Kbulafa al-Râsyidin va Ahl l-Bait alThábirin, (Beirut: Dar al-Fikt, 2005), hal. 54.

${ }^{8}$ M.H. Haikal, Biografi Abu Bakar arb-Shiddiq Khalifab Pertama yang Menentuakan Arah Perjalanan Umat Islam Sepeninggal Rasulillah, (Jakarta: Qisthi, 2007), hal. 137.

9 Jalaluddin Abdurrahman Al-Sayuthi, Târikb al-Khrlafá, Jakarta: Daat al-Kutub alIslamiyyah, 2011), hal. 66 
mengakui pemerintahan Madinah, namun mereka berkata masih mengetahui pemeluk Islam Ja' fariyan.

Heterodoksi agama intinya adalah penyimpangan suatu agama dari ajaran agama yang orisinal menjadi "paham baru"; suatu paham heterodoks pada awalnya tokoh pencetusnya bertolak dari ajaran agama yang baku, kemudian diubah atau diselewengkan ajaran agama yang dianutnya, sehingga menyalahi ajaran prinsip (teologi)-nya. Ajaran agama yang baru ini menjadi berbeda dalam beberapa segi dengan aqidah/teologia ajaran agama yang semula. Ada lembaga yang berperan khusus untuk menetapkan suatu patokan kapan suatu ajaran dipandang telah menyimpang. Dalam kaitannya dengan umat Islam, yang menjadi acuan adalah Majelis Ulama Indonesia (MUI), karena dipandang sebagai wadah yang dapat memberi fatwa bagi kaum Muslim di Indonesia. Sejak awal kelahirannya MUI telah menjadi lembaga yang menyuarakan paham keagamaan yang dapat mengayomi pelaksanaan agama umat, sebagaimana tercermin pada tokoh-tokohnya, yaitu: Buya Hamka, KH. Syukri Ghazali, KH. Hasan Basri, dan KH. Sahal Mahfud. Para pemimpin MUI adalah tokoh-tokoh berkredibilitas tinggi dan mereka adalah pioner-pioner dari kampiun umat Islam. MUI dipandang sebagai lembaga yang memiliki otoritas keagamaan pemberi fatwa yang paling dominan di Negeri ini.

Berkaitan dengan ajaran yang dipandang sesat MUI melalui surat tanggal 25 Syawal 1428/6 Nopember 2007, telah mengeluarkan fatwa tentang Kriteria Sesat suatu ajaran agama, meliputi 10 butir, yaitu: 1) Mengingkari salah satu rukun dari rukun iman yang enam dan rukun Islam yang lima, 2) Meyakini dan atau mengikuti aqidah yang tidak sesuai dengan dalil syar'i, 3) Meyakini turunnya wahyu setelah al-Quran, 4) Mengingkati otentisitas dan atau kebenaran isi alQur'an, 5) Melakukan penafsiran al-Qur'an yang tidak berdasarkan kaidahkaidah tafsir, 6) Mengingkari hadis Nabi sebagai sumber ajaran Islam, 7) Menghina, melecehkan hadis Nabi sebagai sumber ajaran Islam, 8) Mengingkari Nabi Muhammad Saw. sebagai Nabi dan Rasul terakhir, 9) Merubah, menambah . dan atau mengurangi pokok-pokok ibadah yang telab ditetapkan oleh syariah, seperti haji tidak boleh ke Baitullah, shalat fardu tidak 5 waktu, dan 10) 
Mengkafirkan sesama Muslim tanpa dalil sya'i, seperti mengkafirkan Muslim hanya karena bukan kelompoknya.

Implikasi dari fatwa MUI ini menjadikan siapapun yang melanggarnya dipandang sebagai menyimpang dari aqidah Islam, sehingga dapat diklasifikasikan sebagai sesat. Pemberlakuan fatwa tersebut perlu dilakukan secara cermat dan terbuka.

\section{G. Ahmadiyah: Antara Doktrin dan Aplikasi}

Paham Ahmadiyah berasal dari India yang didirikan oleh Mirza Ghulam Ahmad. Proses kemunculannya tidak bisa dilepaskan dari konstelasi politik umat Islam di India pada saat itu. Sejak kekalahan Turki Utsmani dalam serangannya ke benteng Wina tahun 1683 M., pihak Barat mulai bangkit menyerang balik kerajaan tersebut, dan serangan itu lebih meningkat lagi eskalasinya ketika memasuki abad $18^{10}$

Proses berikutnya bangsa Eiopa didotong oleh semangat revolusi industri. Teknologi dan industri melahirkan semangat untuk menyerang bangsa-bangsa muslim lebih gencar. Tetapi operasi jihad yang dikobarkan oleh Syed Ahmad berhasil menggetarkan nyali musuhnya. Sejak itu lawan-lawan Islam gentar bila mendengar kata-kata jihad. Itulah sebabnya mereka berupaya untuk menanamkan benih-benih perpecahan di kalangan pengikut-pengikut syed Ahmad, guna melumpuhkan keampuhan gerakan jihadnya. Sampai akhirnya beberapa suku yang bergabung dengan beliau menggunting dalam lipatan; mereka membocorkan semua rencana Syed Ahmad, dan ketika pasukan Sikh melancarkan serangan dahsyat di lembah Balakot, mereka berbalik membantu musuh-musuh Islam itu" . Lahirnya Ahmadiyah adalah sebagai protes terhadap keberhasilan kaum misionaris kristen karena memperoleh pengikut-pengikut baru, dan terhadap paham rasionalis dan westernisasi Syed Ahmad Khan dengan universitas Aligarhnya ${ }^{12}$.

${ }^{10}$ Wawan Purwanto, Tragedi Cikeusik Pembelajaran dari Kasus Abmadijah. Jakarta: CMB Press, 2011), hal. 59.

11 Wawan Purwanto, Tragedi..., hal. 61.

12 Wawan Purwanto, Tragedi ..., hal. 66. 
Pada awal 1891, Nuruddin Bhairawi telah mengantarkan surat kepada Mirza memintanya supaya menobatkan dirinya sebagai Al-Masih yang dijanjikan. Awalnya, Mirza menolak karena ingin menjadi seorang hamba Allah yang taat saja, tetapi pada tahun yang sama dia menerimanya. Di samping itu, ada motivasi lain dari langkahnya tersebut, yaitu untuk menjaga hubungannya dengan bala tentara kolonial Inggris. Sejak jaman ayah Mirza (Ghulam Murtada), mendapat berbagai fasilitas dan tunjangan hidup dari Inggris. Aliran Ahmadiyah bersikap koperatif dengan Inggris ${ }^{13}$. Paham Ahmadiyah kurang disenangi oleh kaum Muslimin karena paham mereka menyalahi arusbesar (mainstream) umat Islam. Meski tidak disenangi Ahmadiyah tetap mendakwahkan ajarannya secara kooperatif dan membina perekonomiannya. Hodgson menulis:

Abmadiyah sett, which founded late in the nineteenth century by Gbulam Abmad, who claimed to be the Mabdi and used peaceful methods, had succeeded in building an effective social organization, with economic cooperatives and other exemplayy establisbments, but on the basics of strict allegiance to its own particular body, to which other Muslims were expected to be converted. 14

Ahmadiyah terbagi menjadi 2. sekte, yaitu Qadyani dan Lahore. Di Indonesia mereka menggunakan nama Gerakan Ahmadiyah Indonesia (GAD) untuk Lahore, sedangkan Jemaat Ahmadiyah Indonesia (JAI) untuk Qadiani. Pada Lahore, mereka menyatakan bahwa Mirza Ghulam Ahmad hanya sebagai seorang pembaharu. Sedangkan pada Qadyani meyakini bahwa Mirza G. Ahmad sebagai Nabi pembawa wahyu. Bila tidak meyakini seperti maka dipandang sebagai tidak sah Islamnya. Oleh karena itu tidak sah shalat di belakang imam yang tidak masuk Ahmadi (non-Ahmadi). Tidak sah nikah seorang gadis Ahmadiyah dengan laki-laki bukan Ahmadi. Lebih dari itu mereka yang bukan Ahmadi-Qadiyani adalah kafir ${ }^{15}$.

Dalam konteks kehidupan beragama di Indonesia, persoalan Ahmadiyah bukan semata masalah HAM, namun juga masalah teologia umat Islam. Kedua

${ }^{13}$ Wawan Purwanto, Tragedi ..., hal. 70.

14 Marshal G.S. Hodgson, The Venture of Islam 3rd volume, (Chicago and London: The University of Chicago, 1974), hal. 391.

${ }^{15}$ Hamka, Hamka Membahas Soal Soal Islam, ed. Rusydi, (Jakarta: Pustaka Panjimas, 1983), 432. 
persoalan ini berjalan seiring, ibarat sebuah koin mata uang. Kita tidak dapat melihatnya dari satu sisi saja. Di sini ada satu aspek yang perlu dipahami oleh para pengkaji Islam, yaitu konsepsi HAM yang universal. HAM telah diterima oleh dunia Islam dengan baik namun tetap kritis.

Bila tinjauannya aspek HAM maka mereka mesti dijamin kebebasannya untuk menjalankan semua ajaran agama itu. Tetapi karena mereka hidup di masyarakat Muslim Indonesia, di mana populasi penduduk Muslimnya mencapai $86 \%$, maka kebedaan teologia itu menjadi pemantik lahimya konflik Muslim antara jemaah Ahmadiyah dengan non-Ahmadiyah. Ada dua masalah penting di sini, yaitu sisi HAM dan Teologi. Persoalan ini bersisi ganda, yaitu di satu sisi masalah hukum berkaitan dengan HAM, sedangkan di sisi lain yang berkaitan dengan teologi. Kedua masalah ini tidak bisa disimplifikasikan.

Pada sisi HAM; semua manusia harus diperlakukan dengan baik dan bermartabat, karena semua haknya harus dilindungi. Tetapi dari sisi teologinya, dia tidak bisa bertahan dalam keyakinan yang ada, karena dia sudah dipandang telah menodai agama Islam sebagai induknya. Adalah gentle bila Ahmadiyah mendeklarasikan agama barunya, terpisah dari Islam.

Pemimpin Ahmadiyah Nederland, Hibatun Noer Verhagen, yang bersimpati kepada warga Ahmadiyah Indonesia, menyatakan keheranannya mengapa pemimpin Muslim di Indonesia tidak mau mengajak mereka berdialog. Kondisi tersebut mengesankan bahwa Muslim Indonesia tertutup. Ini terjadi akibat dari mereka tidak mampu meyakinkan para pemuka agama Islam di Indonesia dan dunia Islam bila mereka masih setara ajarannya. Karena dalam pandangan para pemimpin Muslim, Ahmadiyah baru akan diajak bicara bila mereka tidak menodai ajaran Islam, dengan berhenti menyatakan kenabian Mirza Ghulam Ahmad, baik sebagai nabi atau nabi źlilli (bayangan dari Muhammad Saw).

Argumentasi mereka yang menyatakan bahwa menafsirkan Mirza Ghulam Ahmad adalah sebagai Nabi tanpa wahyu, karena wahyu Nabi Muhammad Saw. Di sini tampak ambivalensi Ahmadiyah. Di satu sisi dia seolah-oleh mengikuti Nabi Muhammad Saw., tetapi pada sisi lain dia mengklaim bahwa Mirza Ghulam Ahmad adalah Nabi setelah Muhammad Saw. Bila alasan mereka 
dirunut mengapa perlu menyebut Ahmadiyah sebagai Nabi,' padahal dalam pemahaman Muslim hakikat Nabi adalah pribadi pembawa wahyu/kitab suci. Argumentasi mereka dipandang sebentuk ambigu. Alasan Ahmadiyah Qadyani dapat membawa mereka semakin tidak nalar.

Heterodoksi agama merupakan suatu ajaran agama yang memiliki penyimpangan secara sengaja, baik pada teologinya, etika maupun aplikasinya. Heterodoksi beragama pada Ahmadiyah, khususnya Qodyani, dilihat dari teologi, yaitu keyakinan bahwa Mirza Ghulam Ahmad adalah Nabi setelah kenabian Muhammad Saw. Walaupun mereka berdalih bahwa kenabian Mirza G. Ahmadiyah itu tidak dengan membawa wahyu tersendiri, karena Nabinya tetap Muhammad Saw. (nabi Dbilly).

\section{H. Penutup}

Dari uraian di atas dapat disimpulkan berbagai hal sebagai berikut: 1) HAM merupakan upaya legal formal agar manusia dapat mendapatkan hak-haknya, sehingga dia dapat melakukan tugas dan kewajibannya dengan baik, di mana UUD 1945 (amandemen) memberikan Jaminan yang besar bagi Hak Asasi Manusia. 2) Islam membolehkan umat manusia untuk memilih agama yang disenanginya, tetapi bukan untuk menodai agama. Penodaan terhadap suatu agama menjadi sumber konflik antar umat beragama, 3) Ahmadiyah tetap berhak meyakini pahamnya, dengan cara mereka menyatakan keluar dari aqidah Islam, dan membuat agama baru. Bila tidak mau mereka tetap dalam kondisi heterodoksi beragama, yang harus dihindari oleh umat Islam. Karena memantik konflik.

\section{DAFTAR PUSTAKA}

Al-Ba'albaki, M. 1990. Al-Mawrid Qâmus inklisy 'Arabi. Beirut: Dar 'ilm-LilMalayin.

Ali, As'ad Said, 2012. Ideologi Gerakan Pasca-Reformasi. Jakarta: LP3ES. 
Al-Sayuthi, Jalaluddin Abdurrahmah. 2011. Târikh al-Khulafá. (Tashbih wa Ta'liq: Alwi Abu Bakar Muhammad al-Sagaf). Jakarta: Daar al-Kutub al-Islamiyyah. Ath-Thahthawi, Ahmad Abdul 'Aal. 2009. The Great Leaders Kisab Khulafaur Rasyidin. Jakarta: Gema Insani Press.

Boisard, M.A. 1980. Humanisme dalam Islam. (Terj: HM. Rasjidi), Jakarta: Bulan Bintang.

Budi Winamo. 2012. Isu-Isu Global Kontemporer. Jakarta: PT. Buku Seru.

Dagun, Save M. 2005. Kamus Besar Imu Pengetabuan. Jakarta: Lembaga Pengkajian Kebudayaan Nusantara.

Dahlan, Ahmad bin Zainy. 2005. Al-Fath al-Mubân fí Fadbâil al-Kbulafâ al-Rásyidín wa Abl l-Bait al-Tbâbirîn. (Tabqiq: Dr. Rabi bin Shadiq Dablan). Beirut: Dar alFikr.

A. Gauhar. 1983. Tantangan Islam. Terj: Nasir Budiman. Bandung: Pustaka.

Haikal, M.H. 2007. Biografi Abu Bakar asb-Sbiddiq Khalifab Pertama yang Menentuakan Arab Perjalanan Umat Islam Sepeninggal Rasulullab. Jakarta: Qisthi.

Hamka, 1982. Studi Islam. (Ed: H. Rusdi). Jakarta: Pustaka Panjimas.

-----, 1983. Hamka membahas Soal-Soal Islam. (Ed.: Rusydi). Jakarta: Pustaka Panjimas.

Hardiman, F. B. 2011. Hak-Hak Asasi Manusia Polemik dengan Agama dan Kebudayaan. Yogyakarta: Kanisius.

Hodgson, Marshal G.S. 1974. The Venture of Islam 3rd volume. Chicago and London: The University of Chicago.

Hussain, S. 1996. Hak Asasi Manusia dalam Islam. (Terj.: A. Rochim). Jakarta: Gema Insani Press.

Ja'fariyah, Rasul. 2006. Sejarah Khilafah 11-35 H. Jakarta: Penerbit Al-Huda.

Khan, Majid Ali. 1985. Muhammad Saw. Rasul Terakbir. (Terj: Fathul Umam). Bandung: Pustaka Salman ITB.

Kirkpatrick, Betty. 1993. Cassel Concise Englisb Dictionary. Nes edition. London: Cassel. 
Nasution, Harun. dan B. Effendy (editor); (1995). Hak Asasi Manusia dalam Islam. (Penterjemah: Badri Yatim, dkk.), Jakarta: Yayasan Obor Indonesia. Purwanto, Wawan. 2011. Tragedi Cikeusik Pembelajaran dari Kasus Abmadiyah. Jakarta: CMB Press.

Pranawat, R. dan Irfan Abubakar, 2011. Modul Keberagamaan dan Integrasi Sosial. . Jakarta: CSRC UIN Syarif Hidayatullah.

Undang-Undang Dasar 45 dan Amandemennya (Amandemen Pertama sampai. Keempat). Edisi 2011. Bandung: Fokusmedia.

Yogaswara, A. 2008. Hebob Abmadiyah Mengapa Abmadiyab Tidak Langsung Dibubarkan. Yogyakarta: Narasi. 